\title{
Cauda Equina Paraganglioma
}

\author{
Ming-Sound Tsao, Juan Bilbao, Peter Richardson, amd Morrison Finlayson*
}

SUMMARY: Two paragangliomas resected from the cauda equina had similar morphology, both containing cells having dense core secretory granules with no associated sustentacular or supporting cells. The cells were arranged in characteristic lobules that were surrounded by basement membrane and separated by a fibrovascular stroma. This tumor, although rarely found elsewhere in the central nervous system, does occur in the region of the filum terminale, and causes a clinical syndrome typical of tumors in that area.

RÉSUMÉ: Deux paragangliomes de la queue de cheval, de morphologie identique, ont révelé des cellules contenant des granules secrétoires à coeur dense; il n'y avait ni cellule de soutien, ni cellule sus-tentaculaire. Les cellules néoplasiques étaient disposées en lobules caractéristiques, entourés d'une membrane basale et séparés par un stroma fibro-vasculaire. Le paragangliome, rârement retrouvé ailleurs dans le système nerveux central, semble se développer plus fréquemment dans la région du filum terminal. Il donne lieu à un syndrome clinique caractéristique d'une tumeur impliquant cette région.

Can. J. Neurol. Sci. 1983; 10:266-269

Cauda equina paraganglioma has been recognized as a distinct entity only during the past decade, and is now being identified with increasing frequency. The ultrastructural features of these tumors are especially characteristic, and it is likely that the increasing use of electron microscopy in diagnosis will allow clearer separation between the paragangliomas and tumors such as ependymomas which also have a relatively high incidence in this area. We have seen two patients with cauda equina paraganglioma in recent years. Although only ten other cases have been reported, the tumor may be more common than generally realized and it forms a significant proportion of the lesions formerly included with the ependymoma group. The following report gives further information about the nature and clinical significance of these tumors.

\section{Case Reports}

Case 1: A 60 year old man had low back pain for 6 months that radiated to both legs and was aggravated by coughing. There was minimal leg weakness, and the tendon reflexes were normal. Myelography revealed partial blockage by intradural tumor at the level of interspace between the second and third lumbar vertebrae. At operation, a purplish $1.5 \times 2 \mathrm{~cm}$ tumor was found attached to a cauda equina nerve root, and was excised. There was good recovery, but there were continuing medical problems, the most serious being a bronchogenic squamous carcinoma that was discovered and biopsied two years later but could not be resected. There was no clinical evidence of recurrence of the cauda equina 3.5 years after its removal.

Case 2: A 20 year old man had low back pain for 3 months that radiated to the buttocks and left leg, and there was severe pain and muscle spasm of the lower back on movement. There were no sensory or motor defects, and no dysfunction of anal or urinary sphincters. A myelogram showed an intradural tumor at the level of the second lumbar vertebrae, and this was resected along with an adherent nerve root. The tumor was a $1.2 \times 2.2 \mathrm{~cm}$ purplish-red nodule that on cross section appeared encapsulated and contained a few tiny cavities. The only residual symptom was slight cutaneous sensory loss over the left side of the penis, and there is no clinical evidence of recurrence 1 year after resection of the tumor.

\section{Pathology}

\section{Light Microscopy}

The light microscopic appearances of these two tumors were similar. Both tumors were surrounded by a thin fibrous capsule, and in the second case, a few clusters of ependymal cells were incorporated in this capsule. The tumors contained solid areas in which the cells were divided into nests or "cell balls" by thin fibrovascular septa. Most cells within these lobules were in contact with the limiting septa (Fig. 1). They were polygonal or elongated in shape with dark or light staining cytoplasm. The nuclei were oval or round and nucleoli were small or inconspicuous. Mitotic figure was rare or absent. No sustentacular cell was observed. The tumor of case 2 also had many cystic spaces that contained proteinaceous fluid (Fig. 2). When small, these cystic spaces could be seen to encircle small blood vessels.

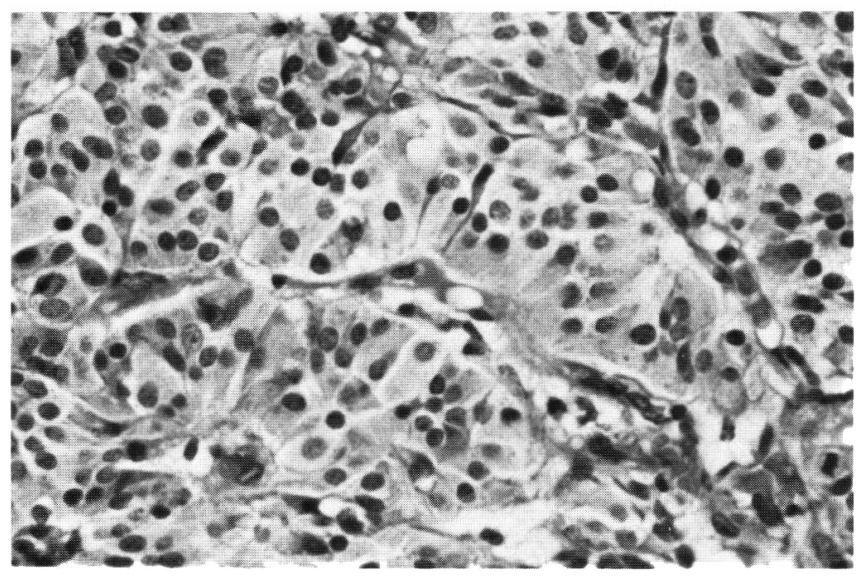

Figure I - Paraganglioma cell nests. Lobules near center appear elongated because plane of section approximates their longitudinal axis. Note that some part of most cells reach limiting membrane of lobule. (Case 2)

From the Department of Pathology, Neurology and Neurosurgery, Montréal General Hospital and McGill University.

* Deceased October 5. 1982. (See obituary in this issue). Received January 3, 1983. Accepted in revised form June $15,1983$.

Reprint requests to: M.-S. Tsao M.D., Department of Pathology. The University of North Carolina, Chapel Hill, N.C. 27514, U.S.A. 


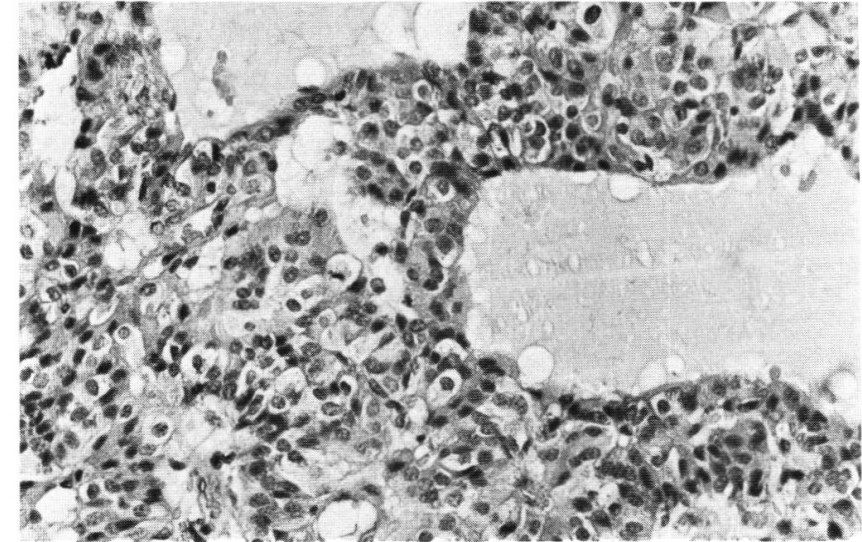

Figure 2 - Solid tumor with microcysts and larger cystic spaces containing proteinaceous fluid. (Case 2 )

Tissue block from case 2 only was available for modified Gremilius stain (Lack and Mercer, 1977) and was negative for argyrophilic granules in tumor cells. The lung tumor of patient 1 was a poorly differentiated squamous cell carcinoma showing marked pleomorphism and brisk mitotic activity. The morphology was distinctly different from that of the previously resected spinal tumor.

\section{Ultrastructure}

Samples of both tumors were fixed in glutaraldehyde, postfixed in osmic acid and embedded in epoxy. On electron microscopy, the blood vessels contained fenestrated endothelium that was surrounded by the usual basement membrane complex.
In most areas the vessels and perivascular collagen were separated from the tumor by a second basal lamina, that encircled the small tumor lobules. The space between these two laminae contained collagen, redundant basement membrane, and variable amounts of basement membrane-like material. Tumor cells, in general had low contrast cytoplasm, but there were a few "dark cells", and both types of cell contained dense core vesicles that were about $150 \mathrm{~nm}$ in diameter. Small elongated mitochondria and occasional small stacks of rough endoplasmic reticulum were other prominent cytoplasmic features. Tumor cells often contained $10 \mathrm{~nm}$ cytoplasmic filaments, and in case 1, many contained prominent masses of these intermediate filaments (Fig. 3). Examination of multiple sections failed to identify any non-secretory or sustentacular cells, and although a few cells displayed a sustentacular-like morphology, when levels were cut through and examined, occasional dense-core secretory granules were always found (Fig. 4). The cystic spaces in the tumor from case 2 appeared to be fluid accumulations in the perivascular stroma, and the parenchymal cells bordering these cavities were the same as those in solid areas of the tumor.

\section{DisCUSSION}

These tumors have a lobular arrangement of cells containing dense core secretory granules that is typical of extra-adrenal paraganglioma. As in other examples from the cauda equina (Miller and Torack 1970, Lerman et al 1972, Horoupian et al 1974, van Alphen et al 1976, Lagacé et al 1978, Llena et al 1979, Llena et al 1982, Binkley et al 1982, Taxy 1983, Soffer et al 1983) proliferation seemed mainly, if not entirely, confined to secretory cells, so that it is unclear whether or not the tumors arise from

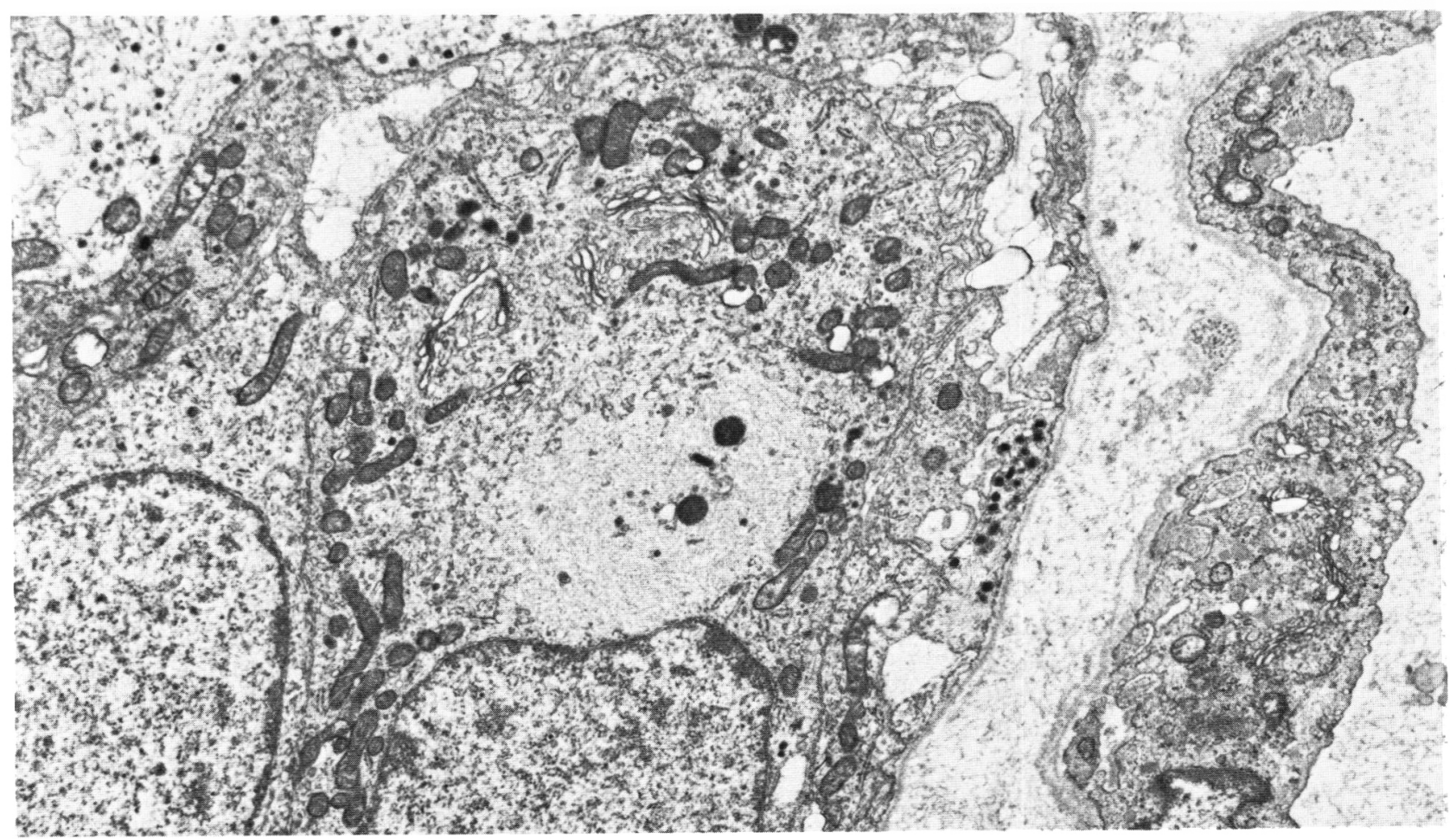

Figure 3 - Secretory cells and adjacent capillary. Secretory cell, with whorl of cytoplasmic filaments is in central field, and in some places is separated from its neighbor by extracellular space. Secretory cells lobule is separated from the blood vessel by basement membrances and extracellular space. (Case I. Uranyl acetate and lead citrate, $12,600 \mathrm{X}$ ) 


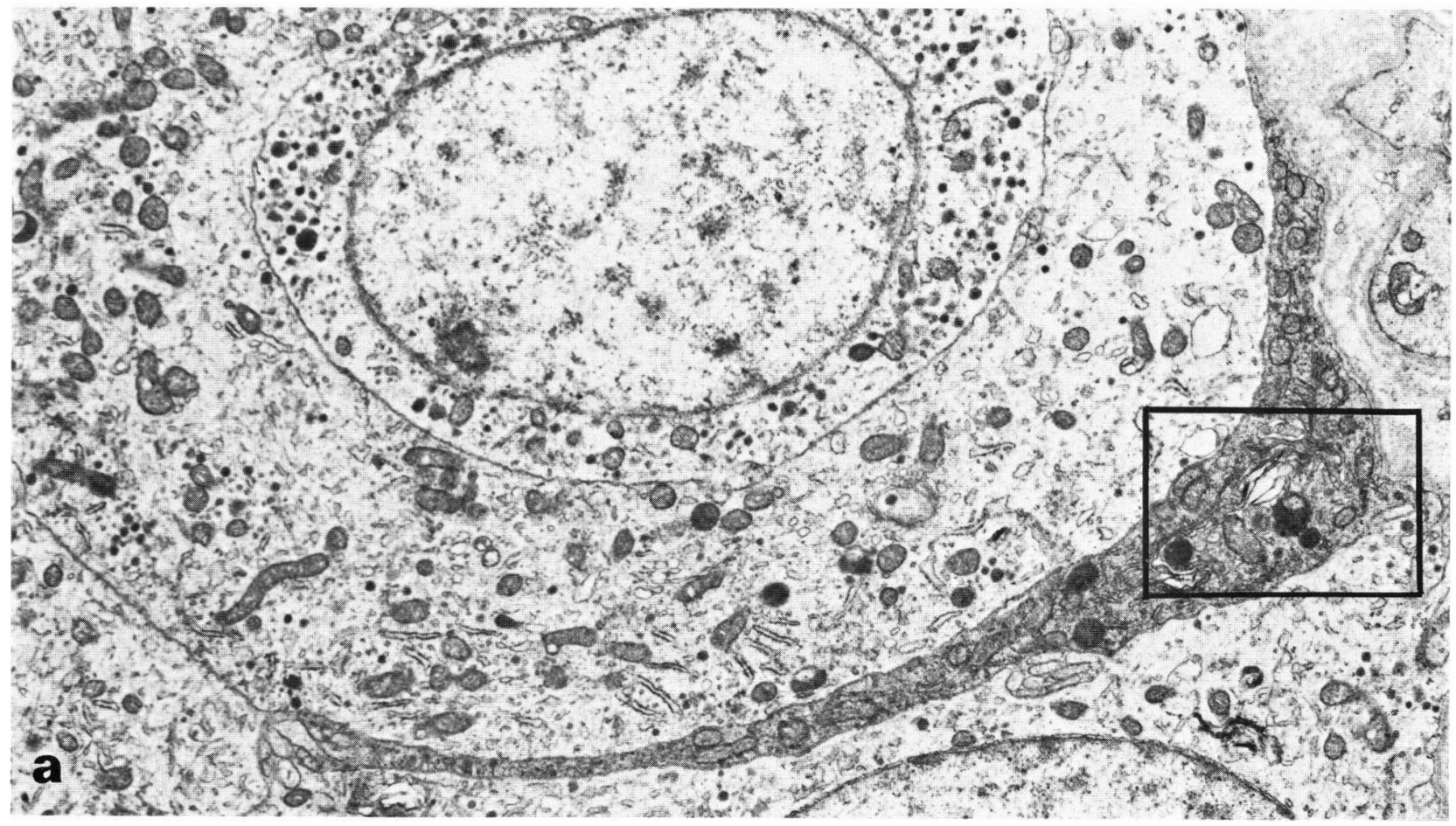

Figure 4 - Secretory cells with dense core granules. (a). The slendor cell with electron dense cytoplasm has the appearance of a supporting cell, but contains secretory granules. The latter, and other secretory cells, are bounded by a basement membrane that is separated from the basement membrane of an adjacent pericyte by collagen, amorphous material, and redundant basement membrances. $(10,000 \mathrm{X})$. (b). Enlargement of squared area showing the secretory granule (arrows). (Case 2. Uranyl acetate and lead citrate)

aggregates like the carotid body that normally contain both secretory and sustentacular cells (Grimley and Glenner, 1967). Of the eleven (including our two) cases that have now been studied by electron microscopy, 2 have had sustentacular-like cells (Horoupian et al 1974, Lagacé et al 1978), but it is not clear if these represented a second cell population, or were merely secretory cells with elongated processes. The architecture of these tumors resembles that of an endocrine gland like the pituitary. There is a similar relationship between blood vessels and secretory cells, and as in some types of pituitary adenoma there are "light" and "dark" secretory cells, and sometimes, globoid masses of intermediate filaments (Lazarides 1980) in the cytoplasm of these cells. Such features are in fact not unusual in various endocrine and neuroendocrine tumors, and probably reflect different stages of activity of the secretory cells, and do not necessarily indicate that there are subpopulations of tumor cells. However, it is evident that tumors of this sort can produce more than one secretory product (Said 1976), so that secretory cells with differing morphology could be a reflection of this fact.

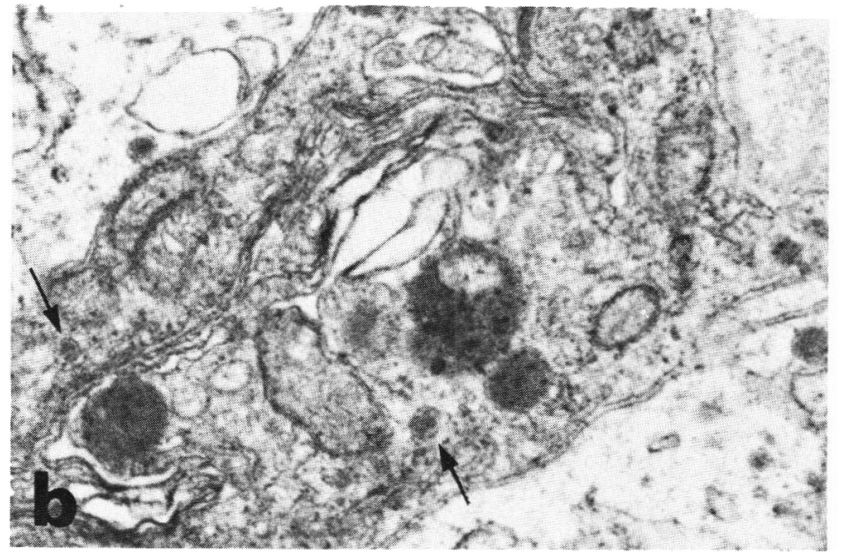

The small ependymal cell nests found in the capsule of one tumor were probably part of the filum terminale. Ependymal cells (Miller and Torack 1970), or neurons (Llena et al 1982), have also been found incorporated within other paragangliomas in this region. Paraganglioma can occur elsewhere within the central nervous system (Bilbao et al 1978), but it is curious that the spinal examples have all been in the region of the filum terminale, and usually at the second or third lumbar level. The retroperitoneal paraganglion tissue is thought to develop from the neural crest in early embryonic life, and perhaps at that time has a function analogous to that of the adrenal medulla in adults (Bolande 1974). It may be that a large proportion of this tissue arises from the lumbar region, and that residual cells in the area occasionally form a growth that is more developmental than neoplastic, and may even include other elements of the developing neuraxis.

The clinical presentation of these tumors, although stereotyped, is not unique and depends more on their location than their nature. Back pain radiating to the lower limbs, and spasm of back muscles have been the commonest symptoms, and although 
dopamine, epinephrine and norepinephrine are produced, there have been no clinical manifestations attributable to the secretion of these catecholamines (Llena et al 1982). Because of their site and vascular nature, there is some danger that hemorrhage from the tumor will complicate lumbar puncture (Horoupian et al 1974), and the spinal fluid protein is often high, probably because of exudation of proteinaceous fluid from the fenestrated blood vessels as seen in case 2 . The average age of onset was 45 years in the 12 cases so far reported, both young adults and the elderly were affected, with a male to female ratio of 8 to 4 . Details of long term follow-up are not available, but it is likely that most patients have been cured by surgery. One patient whose tumor could not be completely removed received postoperative radiotherapy (Lagacé et al 1978), and has remained stable for 5 years (Legacé, personal communication, 1982). Another patient recently reported by Taxy (1983) had a local recurrence 9 years after initial subtotal resection and local irradiation. However, if cauda equina and retroperitoneal paragangliomas are the same, malignancy can be expected, especially when the tumor is not completely resected. In a series of 12 retroperitoneal paragangliomas, 5 had metastases, and there was a positive correlation between metastases and incomplete initial resection, mitoses, and vascular invasion (Lack et al 1980).

\section{ACKNOWLEDGEMENTS}

The authors thank Dr. R. Lagacé for follow-up information on a patient referred to in the text, to Dr. J. Viloria for helpful criticisms and to Celine Lemay for technical assistance.

\section{REFERENCES}

Bilbao, J.M., Horvath, E., Kovacs, K., Singer, W., and Hudson, A.R. (1978). Intrasellar paraganglioma associated with hypopituitarism. Arch Pathol Lab Med 102, 95-98.
Binkley, W., Vakili, S.T., and Worth, R. (1982). Paraganglioma of the cauda equina. Case report. J Neurosurg 56, 275-279.

Bolande, R.P. (1974). The neurocristopathies: a unifying concept of disease arising in neural crest maldevelopment. Hum Pathol 5. 409-429.

Grimley, P.M., and Glenner, G.G. (1967). Histology and ultrastructure of carotid body paraganglioma. Comparison with the normal gland. Cancer 20, 1473-1488.

Horoupian, D.S., Kerson, L.A.. Saiontz. H., and Valsamis. M. (1974). Paraganglioma of the cauda equina. Clinicopathologic and ultrastructural studies of an unusual case. Cancer 33, 1337-1348.

Lack, E. E.. Mercer. L. (1977). A modified Grimelius argyrophil technique for neurosecretory granules. Am J Surg Pathol 1, 275-277.

Lack. E.E.. Cubilla. A.L.. Woodruff. J.M.. and Lieberman. P.H. (1980). Extra-adrenal paragangliomas of the retroperitoneum. A clinicopathologic study of 12 tumors. Am J Surg Pathol 4, 109-120.

Lagacé. R., Delage. C.. and Gagné. F. (1978). Paraganglioma of the filum terminale. Can J Neurol Sci 5. 257-260.

Lazarides, E. (1980). Intermediate filaments as mechanical integrators of cellular space. Nature 283. 249-256.

Lerman, R.I., Kaplan, E.S., and Daman, L. (1972). Ganglioneuromaparaganglioma of the intradural filum terminale. J Neurosurg 36. 652-658.

Llena, J.F., Hirano, A.. and Rubin, R.C. (1979). Paraganglioma in the cauda equina region. Acta Neuropathol (Berl) 46. 235-237.

Llena, J.F., Wisoff, H.S., and Hirano, A. (1982). Gangliocytic paraganglioma in cauda equina region. with biochemical and neuropathological studies. J Neurosurg 56. 280-282.

Miller, C.A., and Torack, R.M. (1970). Secretory ependymoma of the filum terminale. Acta Neuropathol (Berl) 15, 240-250.

Said, S.I. (1976). Evidence for secretion of vasoactive intestinal peptide by tumors of pancreas, adrenal medulla, thyroid and lung: support for the unifying APUD concept. Clin Endocrinol (Oxf) 5. Suppl. $201 \mathrm{~s}-204 \mathrm{~s}$

Soffer, D., Pittaluga, S.. Caine. Y., Feinsod, M. (1983). Paraganglioma of cauda equina. Cancer 51, 1907-1910.

Taxy, J.B. (1983). Paraganglioma of the cauda equina. Cancer 51. 1904-1906.

van Alphen, H.A.M., Bellot, S.M., and Stam, F.C. (1976). Paraganglioma of cauda equina. Clin Neurol Neurosurg 79, 316-322. 